\title{
Corporate Social Responsibility Disclosure and Its Effect on Firm Risk: An Empirical Research on Vietnamese Firms
}

\author{
Cao Thi Mien Thuy ${ }^{1,2}\left(\mathbb{D}\right.$, Nguyen Vinh Khuong ${ }^{2,3, *(\mathbb{D})}$ and Nguyen Thanh Liem ${ }^{1,2}$ (]) \\ 1 Faculty of Finance and Banking, University of Economics and Law, Ho Chi Minh City 700000, Vietnam; \\ thuyctm17704@sdh.uel.edu.vn (C.T.M.T.); liemnt@uel.edu.vn (N.T.L.) \\ 2 Vietnam National University, Ho Chi Minh City 700000, Vietnam \\ 3 Faculty of Accounting and Auditing, University of Economics and Law, Ho Chi Minh City 700000, Vietnam \\ * Correspondence: khuongnv@uel.edu.vn
}

check for updates

Citation: Thuy, C.T.M.; Khuong, N.V.; Liem, N.T. Corporate Social Responsibility Disclosure and Its Effect on Firm Risk: An Empirical Research on Vietnamese Firms. Sustainability 2021, 13, 12933. https://doi.org/10.3390/su132212933

Academic Editor: Andrea Pérez

Received: 25 September 2021 Accepted: 15 November 2021 Published: 22 November 2021

Publisher's Note: MDPI stays neutral with regard to jurisdictional claims in published maps and institutional affiliations.

Copyright: (c) 2021 by the authors. Licensee MDPI, Basel, Switzerland. This article is an open access article distributed under the terms and conditions of the Creative Commons Attribution (CC BY) license (https:// creativecommons.org/licenses/by/ $4.0 /)$.

\begin{abstract}
The purpose of the study was to gather empirical evidence on the influence of corporate social responsibility (CSR) disclosure on firm risk of Vietnam's publicly listed companies. We used adjusted OLS estimation and regression analysis with adjusted panel data for heteroskedasticity and/or autocorrelation to analyze the correlation using data from 225 listed companies on Vietnam's stock market from 2014 to 2019. The study's sample period is relatively recent in the emerging market, especially considering regulatory differences and the availability of voluntary disclosure requirements. The findings of research on the relationship between CSR and corporate risk are mixed, particularly in developing markets. Research findings reveal a negative and significant association between CSR and firm risk, implying that stronger CSR performance lowers a company's risk. This aims to strengthen a research perspective of this connection in emerging countries. Following that, we discuss some policy implications for listed firms and regulators in CSR disclosure.
\end{abstract}

Keywords: corporate social responsibility; firm risk; emerging country

\section{Introduction}

In recent decades, governments, users of financial reporting information, customers, workers, and suppliers have all sought and voiced expectations in terms of the company's CSR initiatives [1-5]. Corporations should be encouraged to disclose more CSR information. As a result, corporations have attempted to adapt to the aforementioned standards in terms of implementing socially responsible acts and environmental protection [4-6]. Companies, on the other hand, are hesitant to devote greater resources to CSR since it diverts resources away from core business operations, perhaps putting the firm in a worse financial situation than it would otherwise be in if it did not take part in corporate social responsibility [7]. On the other hand, it is thought that implementing a CSR strategy will improve the company's image, add possible value to the company, and eliminate potential hazards.

In recent years, a succession of natural catastrophes as a consequence of climate change, and the presence of the COVID 19 pandemic, have highlighted the need of CSR efforts. Importantly, participation in international free trade accords such as the Comprehensive and Progressive Agreement for Trans-Pacific Partnership (CTPPP) and the EU-Vietnam Free Trade Agreement (EVFTA) brings CSR to the forefront concerns in Vietnam. Because the company's business is linked to the global value chain, this is the case [8]. CSR is beneficial to a company's capacity to access foreign markets when it is practiced and disclosed. More crucially, disclosing CSR data can lead to the possibility of attracting funding from investors who adhere to high social and environmental norms. This is the driving force behind some multinational corporations' proactive publication of CSR data in the form of voluntary disclosure [9]. Notably, some listed companies in Vietnam have made sustainable development reports quite early, for example, Vietnam Dairy Products 
Joint Stock Company [10], Hau Giang Pharmaceutical Joint Stock Company [11], Vicostone Joint Stock Company [12].

According to recent studies, CSR disclosure may help firms significantly. CSR disclosure may provide considerable benefits to a firm if it is directed toward the interests of its stakeholders. More significantly, CSR disclosure may be a win-win approach for all stakeholders. Stakeholders' interests are safeguarded when firms conduct and disclose CSR activities. Firms also garner benefits from lower cost of financing from such an involvement in these socially responsible activities [13].

The total risk of a firm (hereafter, firm risk) is the consequence of external or internal variables impacting its profitability [14]. Theoretically, firm risk can be divided into two types: systematic and unsystematic risks [14-16]. Firm risk is the danger that a company's operations may be unclear in the future [17]. Today's global businesses are operating in an unpredictable and risky environment. They are all interested in how to reduce business risk. As a result, if CSR disclosure is helpful, it may be incorporated into a firm's entire risk management strategies.

This research seeks to examine how CSR disclosure affects a firm's risk. This research makes a number of significant contributions. To begin with, the theoretical link between CSR disclosure and firm risk is ambiguous. Furthermore, previous research has primarily focused on the relationship between CSR disclosure and firm risk in developed markets (the United States, the United Kingdom, America, and Europe), with mixed results [14,18-20]. As a result, more research in the context of emerging markets is required to re-evaluate this link, and this is the scope that we will analyze. Second, we find that CSR has recently received much attention in developing countries, but institutions and practices differ from country to country may make findings from one research in a country unfit for the generalization to others. Importantly, even though there are numerous studies on CSR in emerging markets, there is relatively limited research on the link between CSR disclosure and firm risk [21]. Third, CSR has now become a norm and can be seen as a link between business and social and economic growth in Vietnam. Research on the function of CSR disclosure in the Vietnamese context will aid policymakers in building the disclosure framework that benefit both the reporter (the firm) and stakeholders.

The remainder of the research is organized as follows: The study hypotheses are developed in Section 2, research techniques are discussed in Section 3, the empirical findings are summarized and analyzed in Section 4, and lastly, conclusions and suggestions are presented in Section 5.

\section{Literature Review and Hypothesis Development}

In recent decades, both scholars and the general public have paid close attention to non-financial data, notably CSR disclosures [22,23]. As a result, businesses have begun to recognize this trend and incorporated a series of CSR activities into their operations, as well as publishing an annual report that disclose their social activities. The disclosure could be considered as one of the most effective techniques to reach potential investors [24-27].

In addition to potential financial benefits, CSR participation and its disclosure could reduce reputational damage and associated negative consequences. When it comes to CSR, businesses aim to reduce the possibility of a bad outcome [1,28].

In addition to being environmentally friendly, society are increasingly demanding that businesses operate in a socially responsible manner $[29,30]$. This expectation is a logical extension of Stakeholder Theory [26,31,32]. The Legitimacy Theory provides a plausible explanation as to why businesses require societal acceptance to survive and thrive [33,34]. CSR activities have become a standard to seek societal acceptance throughout the world. The first study of non-financial intelligence concentrated on the notion of measurement and its influence on financial performance success [2,35-38].

Firm risk is a risk that has always been existing as a consequence of internal or external factors impacting a firm's operation. For example, an external factor of changes in client demand might result in a sharp decline in sales and a wide fluctuation in an organization's 
stock price, influencing the risk a firm must assume [14]. Internal security vulnerabilities, environments and operations, and market shocks are only some of the dangers that exist. All of these risks may be broken down into three categories: economic, technological, and political risks [39].

Many prior studies have documented considerable evidence of a negative link between corporate social responsibility and risk $[14,40,41]$. However, several empirical investigations $[42,43]$ have shown either a positive or no association. The primary point of our study is that the research results based on the current setting might be entirely different from what has been documented previously because of changing situations in an emerging market. CSR is a concept that has gained a lot of traction in the last decade, and it is considered valuable non-financial information when evaluating firm value. Recent studies on the application of resource-based theory and stakeholder theory, in particular, have brought fresh insights into the present link between CSR and firm risk [22,23,29,44,45].

Several works on the link between CSR disclosure and firm risk have been undertaken. Investors may assign a higher risk level to firms with a higher CSR index, according to previous research [19]. Those firms may encounter a higher cost of capital, for example, or a lower credit rating. According to previous investigation [46], CSR-oriented companies with a diverse set of stakeholders have a higher susceptibility to economic shocks. To put it another way, a company's increased interest in stakeholders raises its firm risk. Furthermore, CSR efforts can deplete a firm's resources, weaken its competitiveness, and make it more sensitive to external shocks [47].

Another study [48] assessed the relationship between CSR and financial risk in the Canadian market between 1995 and 1999. The correlation technique and the portfolio approach were used in this study. The correlation method's findings suggest that the more CSR activities a company engages in, the less risky it becomes. According to the portfolio method, organizations that do not conduct CSR are 70 percent more likely to innovate.

Institutional investors, on the other hand, may see firms with poor CSR as riskier investments [41]. CSR disclosure can be expected to have a negative association with firm risk [15]. While environmental and social disclosures have no influence on a firm's systemic risk, there is a substantial and negative effect of information disclosures on the total risk and unsystematic risk of the firm [15]. Consistent with this argument, unsystematic risk and CSR disclosure have a negative relationship [48,49], but systematic risk and CSR disclosure have a positive relationship [50]. Furthermore, through the indirect output of company reputation, the negative effect of CSR disclosure on firm risk may be more complex [18]. As a result, CSR disclosure is a reasonable investment in a company's reputation. Stakeholder behavior is influenced by reputation, which fosters positive perceptions from stakeholder toward the firm [51]. Employees' perceptions of the company's operations boost the company's long-term viability and stability. For outside investors, reputation is a significant intangible asset that keeps stock values stable in tough times [3], or helps firms survive difficult times with more steady cash flows and less fluctuating stock prices [27]. As a result, CSR disclosure may help to reduce a firm risk through the former's ability to build up the firm's reputation. Another study [20] adds to this argument by claiming that the negative impact of CSR disclosure on firm risk might be due to consumer loyalty. This is because customers tend to show support for ethical businesses during economic downturns [3,52]. Companies that participate in CSR practices are less sensitive to economic downturns because they have more supporting stakeholders [53,54]. Furthermore, even controversial industry firms might lower their risk by engaging in CSR activities [14,21].

There are two conflicting viewpoints on the influence of CSR disclosure on the firm risk, based on Resource Theory and Stakeholder Theory.

Firstly, investment in CSR, according to Resource Theory [55], will shift valuable company resources that might be earmarked for other projects like establishing new product lines or strengthening research and development skills [47]. Excessive concern about the environment, for example, might raise costs and put businesses at a competitive disadvantage. Furthermore, the over-investment hypothesis proposes that managers 
purposefully over-invest in CSR initiatives at the expense of outside shareholders in order to improve their own capability and reputation as responsible executives. Over-investment reduces the value of a firm and increases its risk by having negative effects on its operations. The over-investment effect also implies that CSR disclosure will have a favorable impact on firm risk. Some previous research $[19,46]$ supports Resource Theory's risk-increasing stance.

Secondly, CSR disclosure is directed towards the interests of stakeholders, according to Stakeholder Theory $[4,5,56]$. Firms that do not consider the interests of their stakeholders are more likely to face higher costs in the future [7]. Nonetheless, these expenses may continue to rise as a result of the prospect of regulatory monitor, exacerbating the company's problems. The company that claims to have stronger CSR, on the other hand, will be able to reduce firm risk. Because CSR initiatives may assist businesses in mitigating the effects of adverse events. CSR, for example, can help shield firms from public backlash by reducing the possibility of lawsuits due to unintentional environmental damages. Firms that engage in CSR are more likely to disclose their CSR operations and therefore become more transparent [57]. A higher level of transparent lowers the information asymmetry between the firm and its investors, lowering firm risk. Furthermore, ethical managers are believed to utilize CSR to enhance information transparent, strategy, charity, and, eventually, to minimize firm's total risk $[3,53,54,58-64]$. There are no consistent outcomes across marketplaces throughout the world, based on underlying theory and past study findings. However, the mechanism in place in Vietnam to encourage voluntary non-financial information disclosure is expected to improve financial market transparency. This demonstrates the favorable impact of CSR on business image and risk mitigation. In light of the above research, the authors propose the following hypothesis:

Hypothesis 1. CSR disclosure has a negative effect on firm risk.

\section{Research Design}

\subsection{Data Collection}

The research data covers firms listed on the Ho Chi Minh Stock Exchange (HOSE) and the Hanoi Stock Exchange (HNX). More than 700 firms are listed on HOSE and HNX, with more than 100 in the banking and insurance industries. We choose firms on the basis that they can represent well the industries, so we select firms so that the total market capitalization of firms in the sample is at least 90 percent of the industries. Furthermore, these businesses are more likely to proactively share CSR data and provide complete annual reports. The research sample consists of 225 non-financial businesses that were listed on the Vietnamese stock exchange between 2014 and 2019. Because financial, banking, and securities firms have different characteristics in terms of economic activities and reporting standards, the listed companies chosen for the research sample are nonfinancial organizations. As a result, the authors chose a total number of 225 businesses, comprising 159 companies listed on HOSE and 66 companies listed on HNX. CSR data is obtained from sustainability reports and annual reports of companies listed on the Vietnamese stock market. The financial data is provided from Refinitiv Eikon.

\subsection{Research Models}

To assess the impact of CSR disclosure on firm risk, the authors construct the following model that is in line with previous studies $[14,15,21]$ :

$$
\mathrm{FR}_{\mathrm{it}}=\delta_{0}+\delta_{1} \mathrm{CSR}_{\mathrm{it}}+\delta_{2} \mathrm{SIZE}_{\mathrm{it}}+\delta_{3} \mathrm{LEV}_{\mathrm{it}}+\delta_{4} \mathrm{ROA}_{\mathrm{it}}+\delta_{5} \mathrm{GROW}_{\mathrm{it}}+\delta_{6} \mathrm{AGE}_{\mathrm{it}}+\mathrm{INDUSTRY}_{\mathrm{i}}+\varepsilon_{\mathrm{it}}
$$

In which,

$i=1,2, \ldots, 225$ (where i represents 225 listed companies);

$t=1,2,3, \ldots, 6$ (where $t$ is the period of 6 years, from 2014 to 2019);

FR: Dependent variable that measures firm risk $i$ at year $t$ using two proxies: VOLATILITY and VOL_DUM, inherited from previous studies $[14,15,21]$. 
CSR: the main independent variable that represents CSR disclosure of firm $i$ at year $t$. This variable has four proxies: CSR_ALL, CSR_ECO, CSR_ENV, CSR_SOC (Appendix A). These are indices that are created using the content analysis method.

SIZE: control variable (SIZE $=\mathrm{Ln}$ (Total assets)) that shows the size of firm $\mathrm{i}$ in year $\mathrm{t}[14,15,19,65]$.

LEV: control variable, measured as the ratio of business i's total liabilities to total assets in year $t$ (LEV = Total liabilities/Total assets) $[14,15,19,65]$.

ROA: control variable that depicts the profitability of firm $\mathrm{i}$ in year $\mathrm{t}(\mathrm{ROA}=$ Profit after taxes/Total assets) $[14,15,18,65]$.

GROW: control variable that represents business i's revenue growth in year $\mathrm{t}$ (GROW $=($ This year's revenue - Previous year's revenue $) /$ Previous year's revenue $)[14,18]$.

AGE: Control variable indicating the age of the firm i's listing in time $t$ (AGE = Ln(listing age)), adopted from prior research $[19,65]$.

INDUSTRY: The industry effects are all controlled by the vector control variable INDUSTRY. We use Thomson Reuters industry categorization standards. The industries include Basic Materials, Consumer Cyclicals, Consumer Non-Cyclicals, Energy, Healthcare, Industrials, Technology, and Utilities.

$\delta 1, \delta 2, \ldots \delta 6$ : the regression coefficient quantifies the change in the dependent variable per unit change in the independent variable when the values of all independent variables are constant.

$\varepsilon_{i t}:$ the error.

To sum up, SIZE, LEV, ROA, GROW, and AGE are control variables for company size, financial leverage, profitability, revenue growth, and listing age, respectively. In addition, the authors utilize industry dummy variables, which correspond to industries according to the Thomson Reuters database's industry categorization criteria, to control the impact on the field's potential firm business risk, in line with prior research $[14,15,18,65]$.

\subsection{Methodology}

To assess the research findings, the authors utilize the OLS estimate technique. OLS estimations, however, will not be efficient in the presence of heteroskedasticity issue. Furthermore, autocorrelation causes the $t$-value (or the $p$-value) to be higher than it should be, and the regression coefficients to be statistically significant. Even when the sample is big, the estimates become increasingly incorrect if this event happens simultaneously with fluctuating variance. Hence, we utilize Linear regression with panel-corrected standard errors (xtpcse) or fit panel-data models using Generalized least squares (xtgls) to handle data with heteroskedasticity and/or autocorrelation issues. The authors also utilize the logit model with the measure of the binary variable of the dependent variable in the research and analysis based on data grouping to assess the stability of the research findings.

\section{Research Results and Discussion}

\subsection{Descriptive Statistics}

Table 1 summarizes the descriptive statistics for the study variables.

Table 1. Descriptive statistics of variables.

\begin{tabular}{cccccc}
\hline Variable & Obs & Mean & Std. Dev. & Min & Max \\
\hline Volatility & 1249 & 0.051 & 0.022 & 0.143 & 0.155 \\
CSR_ALL & 1350 & 0.262 & 0.145 & 0 & 0.939 \\
Size & 1340 & 28.237 & 1.298 & 23.33 & 32.253 \\
Lev & 1330 & 0.246 & 0.188 & 0 & 0.736 \\
Roa & 1332 & 0.096 & 0.091 & -0.316 & 0.589 \\
Grow & 1317 & 0.190 & 0.705 & -0.851 & 9.203 \\
Age & 1340 & 2.791 & 0.471 & 0.693 & 4.787 \\
\hline
\end{tabular}

Source: Author's calculations from research sample. 
Table 1 shows that the variable VOLATILITY has a positive mean value of 0.051 , suggesting that the firm risk of listed businesses in the sample is relatively high, almost the same as previously reported $[14,21]$ in stock markets such as the United States and Indonesia. This is also consistent with emerging stock markets like Vietnam's high volatility. The CSR variable has an average value of 0.262 and a standard deviation of 0.145 , indicating that the sample's degree of CSR disclosure is still low when compared to the GRI standards in Vietnam. This statistic also roughly equals the amount of CSR disclosure in the Indonesian emergent stock market [21]. LEV has an average value of 0.246, implying that total debt accounts for about a quarter of total assets. The average ROA in the sample is 0.096 , with a standard deviation of 0.091, indicating that the firms have strong growth potential on average. GROW has an average score of 0.190 , which corresponds to a rate of 19.0 percent, indicating rather strong revenue growth for businesses. According to the Vietnamese stock market's operation period, AGE has an average value of 2791, which corresponds to the average listing age of firm between 16 and 17 years old.

\subsection{Correlation Analysis}

Correlation analysis is a method of determining the strength of a link between two variables. The two variables are treated as "equal" variables, regardless of whether they are independent or dependent.

There is no severe multicollinearity in the model, since no pairwise correlation coefficient has an absolute value larger than 0.9 , as shown in Table 2 [66].

Table 2. The correlation matrix.

\begin{tabular}{ccccccc}
\hline Variable & Volatility & CSR_ALL & Size & Lev & Roa & Grow \\
\hline Volatility & 1.000 & & & & & \\
CSR_ALL & $-0.221^{*}$ & 1.000 & & & & \\
Size & $-0.152 *$ & $0.292^{*}$ & 1.000 & & & \\
Lev & 0.034 & 0.000 & $0.339^{*}$ & 1.000 & & \\
Roa & -0.287 & $0.104^{*}$ & $-0.234^{*}$ & $-0.441^{*}$ & 1.000 & 1.000 \\
Grow & 0.054 & $-0.082^{*}$ & -0.016 & -0.031 & 0.023 & $-0.156^{*}$ \\
Age & 0.048 & $0.113^{*}$ & 0.013 & $0.063^{*}$ & 0.007 & 1.000 \\
\hline
\end{tabular}

${ }^{*} p<0.05$. Source: Author's calculations from Stata.

\subsection{Main Results}

Table 3 shows the regression analysis findings, with columns 1-4 presenting the estimation results corresponding to the CSR disclosure proxy being CSR_ALL, CSR_ECON, CSR_ENV, and CSR_SOC measures, respectively.

As shown in Table 3, the results confirm a negative relationship between CSR disclosure and firm risk. The coefficient of the CSR_ALL (column 1) is negative and statistically significant $(-0.019, p<1 \%)$. This implies that the degree of CSR disclosure is negatively related to firm risk. This finding supports extant works $[14,15,18,20,21,54,65]$ and is in line with the belief that CSR disclosure are less likely to spread bad news and exhibit higher levels of transparency, resulting in lower firm risk. As a result, the authors' study hypothesis $\mathrm{H} 1$ has been confirmed.

The influence of each CSR disclosure dimensions on firm risk is also examined by the authors. The authors examine three key themes, including economic (CSR_ECON), the environmental (CSR_ENV), and social (CSR_SOC), according to GRI criteria. The authors find the negative impact of two CSR disclosure dimensions (environmental and social perspectives) on the firm risk. At first, the coefficient of the variable CSR_ECON in Table 3, column 2 , is negative and not statistically significant $(-0.002, p>10 \%)$, despite the fact that the negative coefficient is consistent with that of the two other measures. This negative coefficient might imply that economic-thematic CSR disclosure has a negative impact on firm risk, but the evidence is weak. The coefficient of variable CSR_ENV is negative and statistically significant $(-0.012, p<1 \%)$, demonstrating the negative relationship between 
environmental-thematic CSR disclosure and firm risk (Table 3, column 3). Similarly, the coefficient of the CSR_SOC variable is negative and statistically significant $(-0.016, p<1 \%)$ in the last column of Table 3, column 4. This negative coefficient also explains the negative impact of social-thematic CSR disclosure on firm risk. Overall, it is clear that CSR disclosure on environmental and social dimensions tends to reduce firm risk. This finding is in line with the findings of a recent research [15], and it supports the theory that the negative link between CSR disclosure and firm risk is mostly driven by collective effects of all dimensions are represented, although not fully by any one of them.

Table 3. Regression results according to OLS method.

\begin{tabular}{|c|c|c|c|c|}
\hline Variables & Model 1 & Model 2 & Model 3 & Model 4 \\
\hline CSR_ALL & $\begin{array}{c}-0.019 * * * \\
{[-4.94]}\end{array}$ & & & \\
\hline CSR_ECON & & $\begin{array}{c}-0.002 \\
{[-0.61]}\end{array}$ & & \\
\hline CSR_ENV & & & $\begin{array}{c}-0.012 * * * \\
{[-5.09]}\end{array}$ & \\
\hline CSR_SOC & & & & $\begin{array}{c}-0.016 \text { *** } \\
{[-4.14]}\end{array}$ \\
\hline Roa & $\begin{array}{c}-0.077^{* * *} \\
{[-9.78]}\end{array}$ & $\begin{array}{c}-0.081^{* * *} \\
{[-10.25]}\end{array}$ & $\begin{array}{c}-0.078^{* * *} \\
{[-9.93]}\end{array}$ & $\begin{array}{c}-0.078^{* * * *} \\
{[-9.83]}\end{array}$ \\
\hline Size & $\begin{array}{c}-0.004 * * * \\
{[-6.85]}\end{array}$ & $\begin{array}{c}-0.004^{* * *} \\
{[-7.56]}\end{array}$ & $\begin{array}{c}-0.004^{* * *} \\
{[-7.12]}\end{array}$ & $\begin{array}{c}-0.004^{* * *} \\
{[-7.31]}\end{array}$ \\
\hline Lev & $\begin{array}{c}-0.003 \\
{[-0.90]}\end{array}$ & $\begin{array}{l}-0.003 \\
{[-0.74]}\end{array}$ & $\begin{array}{l}-0.004 \\
{[-1.09]}\end{array}$ & $\begin{array}{l}-0.003 \\
{[-0.72]}\end{array}$ \\
\hline Grow & $\begin{array}{c}0.002 \\
{[1.35]}\end{array}$ & $\begin{array}{c}0.002 \\
{[1.49]}\end{array}$ & $\begin{array}{l}0.001 \\
{[1.19]}\end{array}$ & $\begin{array}{c}0.002 \\
{[1.47]}\end{array}$ \\
\hline Age & $\begin{array}{c}-0.004 * * \\
{[-2.57]}\end{array}$ & $\begin{array}{c}-0.004^{* * *} \\
{[-2.96]}\end{array}$ & $\begin{array}{c}-0.003^{* *} \\
{[-2.39]}\end{array}$ & $\begin{array}{c}-0.004^{* * *} \\
{[-2.73]}\end{array}$ \\
\hline _Cons & $\begin{array}{c}0.170 * * * \\
{[11.26]}\end{array}$ & $\begin{array}{c}0.184 * * * \\
{[11.87]}\end{array}$ & $\begin{array}{c}0.178^{* * *} \\
{[11.40]}\end{array}$ & $\begin{array}{c}0.177^{* * *} \\
{[11.76]}\end{array}$ \\
\hline Industry & Yes & Yes & Yes & Yes \\
\hline $\mathrm{N}$ & 1227 & 1227 & 1227 & 1227 \\
\hline R-sq & 0.19 & 0.177 & 0.194 & 0.185 \\
\hline
\end{tabular}

The model's control variables all have an influence on the firm risk, which is consistent with past studies $[14,15,18,19,65]$. Companies that have a high total asset size and profitability, for example, are less susceptible to firm risk $[14,15,65]$. Beside, long-term listed firms, have a number of benefits in terms of reputation, size, and long-term asset age, as well as market awareness, and are thus negatively linked to the firm risk [19].

Examining the data, we discovered that there is within-panel heteroskedastic errors but no auto correlation between panels. As a result, the authors use linear regression with panel-corrected standard errors to address the problem of heteroskedasticity. Table 4 displays the results of the regression analysis. Based on the findings in Table 4, the authors conclude that CSR disclosure has a negative impact on the firm risk. As a result, the coefficient of the CSR variable in Table 4, column 1, is negative and statistically significant $(-0.019, p<1 \%)$, indicating that CSR disclosure has a negative impact on the firm risk. Similarly, the coefficients of two variables CSR_ENV and CSR_SOC in Table 4, column 3-4, are both negative and statistically significant $(-0.012, p<1 \%$ and $-0.016, p<1 \%$, respectively), indicating the negative impact of CSR disclosure on environmental and social topics on the firm risk. In addition, the coefficient of the CSR_ECON variable in column 2 of Table 4 is negative but not statistically significant $(-0.002, p>10 \%)$. This negative coefficient, however, has the same sign as other CSR disclosure metrics. This demonstrates that the dimension of economic CSR disclosure contribute to CSR disclosure's negative impact on the firm risk. This finding is in line with earlier study [15] and supports the theory that the negative link between CSR disclosure and firm risk is mostly driven by the combined 
impacts of all dimensions, rather than any one. Furthermore, the regression findings in Table 4 demonstrate that control factors have an impact on firm risk, which is consistent with previous studies $[14,15,65]$.

Table 4. Regression results according to XTPCSE method.

\begin{tabular}{|c|c|c|c|c|}
\hline Variables & Model 1 & Model 2 & Model 3 & Model 4 \\
\hline CSR_ALL & $\begin{array}{c}-0.019 * * * \\
{[-5.09]}\end{array}$ & & & \\
\hline CSR_ECO & & $\begin{array}{l}-0.002 \\
{[-0.61]}\end{array}$ & & \\
\hline CSR_ENV & & & $\begin{array}{c}-0.012 * * * \\
{[-5.25]}\end{array}$ & \\
\hline CSR_SOC & & & & $\begin{array}{c}-0.016^{* * *} \\
{[-4.23]}\end{array}$ \\
\hline Roa & $\begin{array}{c}-0.077^{* * * *} \\
{[-9.68]}\end{array}$ & $\begin{array}{c}-0.081^{* * *} \\
{[-10.14]}\end{array}$ & $\begin{array}{c}-0.078 * * * \\
{[-9.76]}\end{array}$ & $\begin{array}{c}-0.078^{* * * *} \\
{[-9.73]}\end{array}$ \\
\hline Size & $\begin{array}{c}-0.004^{* * * *} \\
{[-6.58]}\end{array}$ & $\begin{array}{c}-0.004^{* * *} \\
{[-7.21]}\end{array}$ & $\begin{array}{c}-0.004 * * * \\
{[-6.88]}\end{array}$ & $\begin{array}{c}-0.004^{* * * *} \\
{[-7.01]}\end{array}$ \\
\hline Lev & $\begin{array}{l}-0.003 \\
{[-0.93]}\end{array}$ & $\begin{array}{l}-0.003 \\
{[-0.76]}\end{array}$ & $\begin{array}{l}-0.004 \\
{[-1.12]}\end{array}$ & $\begin{array}{l}-0.003 \\
{[-0.74]}\end{array}$ \\
\hline Rev_grow & $\begin{array}{l}0.002 \\
{[1.22]}\end{array}$ & $\begin{array}{l}0.002 \\
{[1.38]}\end{array}$ & $\begin{array}{l}0.001 \\
{[1.10]}\end{array}$ & $\begin{array}{l}0.002 \\
{[1.33]}\end{array}$ \\
\hline Age & $\begin{array}{c}-0.004^{* * *} \\
{[-2.62]}\end{array}$ & $\begin{array}{c}-0.004^{* * *} \\
{[-3.02]}\end{array}$ & $\begin{array}{c}-0.003^{* *} \\
{[-2.44]}\end{array}$ & $\begin{array}{c}-0.004^{* * *} \\
{[-2.79]}\end{array}$ \\
\hline _Cons & $\begin{array}{c}0.170 * * * \\
{[10.83]}\end{array}$ & $\begin{array}{c}0.184^{* * *} \\
{[11.31]}\end{array}$ & $\begin{array}{c}0.178^{* * * *} \\
{[10.99]}\end{array}$ & $\begin{array}{c}0.177^{* * * *} \\
{[11.28]}\end{array}$ \\
\hline Industry & Yes & Yes & Yes & Yes \\
\hline $\mathrm{N}$ & 1227 & 1227 & 1227 & 1227 \\
\hline R-sq & 0.19 & 0.177 & 0.194 & 0.185 \\
\hline
\end{tabular}

$t$ statistics in brackets. ${ }^{* *} p<0.05,{ }^{* * *} p<0.01$. Source: Author's calculations from research sample.

\subsection{Robustness Tests}

\subsubsection{Alternative Measure of Dependent Variable}

We further use a logit regression model to conduct the study and uses the binary variable of the dependent variable as a metric. Table 5 summarizes the findings of the regression analysis using the logit model. Based on the findings in Table 5, we can again confirm the negative impact of CSR disclosure on firm risk, which is consistent with prior experimental findings. Environmental and social disclosure dimensions have a negative influence on the firm risk, according to a deeper examination of CSR disclosure dimensions. However, there is no statistical evidence that the economic CSR disclosure dimension has a detrimental impact on the firm risk. Not all aspects of CSR disclosure (economic, social, and environmental perspectives) interact in the same way with the firm risk. However, this is also consistent with previous studies $[15,67,68]$ that suggest a company's commitment and involvement in social and environmental activities to being a good citizen and respecting business ethics helps to reduce the firm risk.

\subsubsection{Analysis Based on Data Grouping}

Based on the median value of VOLATILITY variable, the authors divide the research sample into two groups: High Risk and Low Risk. Table 6 shows the results of the OLS regression analysis for each group. Based on Table 6, the authors find that the negative effect of CSR disclosure on the firm risk only occurs in the High Risk group and there is no similar evidence in the Low Risk group. That is, CSR disclosure reduces risk in companies that have a greater firm risk than those that have a lower firm risk. This finding is in consistent with the other studies $[14,21,63,64]$ and supports the notion that CSR is more prominent among firms engaged in controversial industry sectors including alcohol, tobacco, gambling, and mining, etc. 
Table 5. Regression results according to LOGIT method.

\begin{tabular}{|c|c|c|c|c|}
\hline Variables & Model 1 & Model 2 & Model 3 & Model 4 \\
\hline CSR_ALL & $\begin{array}{c}-1.499 * * * \\
{[-3.03]}\end{array}$ & & & \\
\hline CSR_ECON & & $\begin{array}{l}0.102 \\
{[0.22]}\end{array}$ & & \\
\hline CSR_ENV & & & $\begin{array}{c}-0.757 * * * \\
{[-3.08]}\end{array}$ & \\
\hline CSR_SOC & & & & $\begin{array}{c}-1.557^{* * *} \\
{[-3.01]}\end{array}$ \\
\hline Roa & $\begin{array}{c}-5.658 * * * \\
{[-6.42]}\end{array}$ & $\begin{array}{c}-5.945^{* * *} \\
{[-6.72]}\end{array}$ & $\begin{array}{c}-5.7333^{* * *} \\
{[-6.52]}\end{array}$ & $\begin{array}{c}-5.655^{* * *} \\
{[-6.41]}\end{array}$ \\
\hline Size & $\begin{array}{c}-0.266 * * * \\
{[-4.35]}\end{array}$ & $\begin{array}{c}-0.314^{* * *} \\
{[-5.05]}\end{array}$ & $\begin{array}{c}-0.278^{* * *} \\
{[-4.61]}\end{array}$ & $\begin{array}{c}-0.277^{* * *} \\
{[-4.59]}\end{array}$ \\
\hline Lev & $\begin{array}{l}0.313 \\
{[0.81]}\end{array}$ & $\begin{array}{l}0.358 \\
{[0.95]}\end{array}$ & $\begin{array}{c}0.265 \\
{[0.69]}\end{array}$ & $\begin{array}{l}0.374 \\
{[0.97]}\end{array}$ \\
\hline Grow & $\begin{array}{l}0.097 \\
{[0.74]}\end{array}$ & $\begin{array}{l}0.117 \\
{[0.86]}\end{array}$ & $\begin{array}{l}0.087 \\
{[0.66]}\end{array}$ & $\begin{array}{c}0.11 \\
{[0.83]}\end{array}$ \\
\hline Age & $\begin{array}{l}-0.260 * \\
{[-1.82]}\end{array}$ & $\begin{array}{c}-0.294^{* *} \\
{[-2.07]}\end{array}$ & $\begin{array}{l}-0.249 * \\
{[-1.74]}\end{array}$ & $\begin{array}{l}-0.272 * \\
{[-1.91]}\end{array}$ \\
\hline _Cons & $\begin{array}{c}7.553 * * * \\
{[4.32]}\end{array}$ & $\begin{array}{c}8.586 * * * \\
{[4.86]}\end{array}$ & $\begin{array}{c}7.738^{* * *} \\
{[4.45]}\end{array}$ & $\begin{array}{c}7.865^{* * *} \\
{[4.54]}\end{array}$ \\
\hline Industry & Yes & Yes & Yes & Yes \\
\hline $\mathrm{N}$ & 1227 & 1227 & 1227 & 1227 \\
\hline $\mathrm{R}-\mathrm{sq}$ & 0.0905 & 0.0843 & 0.0899 & 0.0907 \\
\hline
\end{tabular}

$t$ statistics in brackets. ${ }^{*} p<0.1,{ }^{* *} p<0.05,{ }^{* * *} p<0.01$. Source: Author's calculations from research sample.

Table 6. Regression results according to High Risk and Low Risk.

\begin{tabular}{|c|c|c|c|c|c|c|c|c|}
\hline \multirow[b]{2}{*}{ Variables } & \multicolumn{4}{|c|}{ High Risk } & \multicolumn{4}{|c|}{ Low Risk } \\
\hline & Model 1 & Model 2 & Model 3 & Model 4 & Model 1 & Model 2 & Model 3 & Model 4 \\
\hline CSR_ALL & $\begin{array}{c}-0.017^{* * *} \\
{[-3.85]}\end{array}$ & & & & $\begin{array}{l}-0.003 \\
{[-1.33]}\end{array}$ & & & \\
\hline CSR_ECON & & $\begin{array}{c}-0.007 \\
{[-1.41]}\end{array}$ & & & & $\begin{array}{c}-0.003 \\
{[-1.34]}\end{array}$ & & \\
\hline CSR_ENV & & & $\begin{array}{c}-0.012 * * * \\
{[-3.98]}\end{array}$ & & & & $\begin{array}{c}-0.001 \\
{[-1.10]}\end{array}$ & \\
\hline CSR_SOC & & & & $\begin{array}{c}-0.0122^{* * *} \\
{[-2.71]}\end{array}$ & & & & $\begin{array}{l}-0.002 \\
{[-0.90]}\end{array}$ \\
\hline Roa & $\begin{array}{c}-0.074^{* * *} \\
{[-7.24]}\end{array}$ & $\begin{array}{c}-0.076^{* * *} \\
{[-7.25]}\end{array}$ & $\begin{array}{c}-0.073^{* * *} \\
{[-7.21]}\end{array}$ & $\begin{array}{c}-0.076^{* * *} \\
{[-7.31]}\end{array}$ & $\begin{array}{c}-0.011^{* * *} \\
{[-3.02]}\end{array}$ & $\begin{array}{c}-0.012 * * * \\
{[-3.21]}\end{array}$ & $\begin{array}{c}-0.011^{* * *} \\
{[-3.15]}\end{array}$ & $\begin{array}{c}-0.011^{* * *} \\
{[-3.06]}\end{array}$ \\
\hline Size & $\begin{array}{c}-0.003 * * * \\
{[-4.79]}\end{array}$ & $\begin{array}{c}-0.003 * * * \\
{[-5.23]}\end{array}$ & $\begin{array}{c}-0.003^{* * *} \\
{[-4.70]}\end{array}$ & $\begin{array}{c}-0.003^{* * *} \\
{[-5.11]}\end{array}$ & $\begin{array}{l}-0.000 \\
{[-1.36]}\end{array}$ & $\begin{array}{l}-0.000 \\
{[-1.13]}\end{array}$ & $\begin{array}{l}-0.000 \\
{[-1.55]}\end{array}$ & $\begin{array}{l}-0.000 \\
{[-1.55]}\end{array}$ \\
\hline Lev & $\begin{array}{l}-0.005 \\
{[-1.04]}\end{array}$ & $\begin{array}{l}-0.004 \\
{[-0.90]}\end{array}$ & $\begin{array}{l}-0.006 \\
{[-1.26]}\end{array}$ & $\begin{array}{l}-0.005 \\
{[-0.99]}\end{array}$ & $\begin{array}{l}-0.000 \\
{[-0.23]}\end{array}$ & $\begin{array}{l}-0.001 \\
{[-0.34]}\end{array}$ & $\begin{array}{l}-0.001 \\
{[-0.25]}\end{array}$ & $\begin{array}{l}-0.000 \\
{[-0.14]}\end{array}$ \\
\hline Grow & $\begin{array}{l}0.002 \\
{[1.59]}\end{array}$ & $\begin{array}{c}0.002 \text { * } \\
{[1.87]}\end{array}$ & $\begin{array}{l}0.002 \\
{[1.39]}\end{array}$ & $\begin{array}{c}0.002 * \\
{[1.77]}\end{array}$ & $\begin{array}{c}0.001 \text { * } \\
{[1.91]}\end{array}$ & $\begin{array}{c}0.001 \text { * } \\
{[1.96]}\end{array}$ & $\begin{array}{c}0.001 \text { * } \\
{[1.85]}\end{array}$ & $\begin{array}{c}0.001 * \\
{[1.96]}\end{array}$ \\
\hline Age & $\begin{array}{l}-0.003 * \\
{[-1.79]}\end{array}$ & $\begin{array}{l}-0.003 * \\
{[-1.86]}\end{array}$ & $\begin{array}{l}-0.003 \\
{[-1.57]}\end{array}$ & $\begin{array}{l}-0.003^{*} \\
{[-1.84]}\end{array}$ & $\begin{array}{l}-0.000 \\
{[-0.43]}\end{array}$ & $\begin{array}{l}-0.000 \\
{[-0.56]}\end{array}$ & $\begin{array}{l}-0.000 \\
{[-0.46]}\end{array}$ & $\begin{array}{l}-0.000 \\
{[-0.53]}\end{array}$ \\
\hline _Cons & $\begin{array}{c}0.174^{* * *} \\
{[8.63]}\end{array}$ & $\begin{array}{c}0.181^{* * *} \\
{[8.90]}\end{array}$ & $\begin{array}{c}0.170^{* * * *} \\
{[8.52]}\end{array}$ & $\begin{array}{c}0.180^{* * * *} \\
{[8.82]}\end{array}$ & $\begin{array}{c}0.050 * * * \\
{[5.74]}\end{array}$ & $\begin{array}{c}0.049^{* * *} \\
{[5.42]}\end{array}$ & $\begin{array}{c}0.051 * * * \\
{[5.94]}\end{array}$ & $\begin{array}{c}0.051^{* * *} \\
{[6.01]}\end{array}$ \\
\hline Industry & Yes & Yes & Yes & Yes & Yes & Yes & Yes & Yes \\
\hline $\mathrm{N}$ & 615 & 615 & 615 & 615 & 612 & 612 & 612 & 612 \\
\hline R-sq & 0.161 & 0.149 & 0.169 & 0.154 & 0.084 & 0.084 & 0.083 & 0.082 \\
\hline
\end{tabular}




\section{Conclusions and Implications}

\subsection{Conclusions}

The study's goal is to see how CSR disclosure affects firm risk for companies listed on two Vietnamese stock exchanges. From 2014 to 2019, the study sample covers 225 nonfinancial firms listed on the two stock exchanges HOSE and HNX. It originates from a disparity in previous study findings on this topic in developed and underdeveloped countries. We investigate the connection between CSR and corporate risk in a developing country with no regulatory framework in place. We show evidence that public companies with higher CSR disclosure have lower firm risk, which is consistent with the Stakeholder Theory argument that CSR disclosure improves the company's image with its stakeholders, bringing reputation value as well as customers to the company. According to the view that socially responsible organizations are less likely to convey bad news and are more transparent, lowering firm risk. Simultaneously, this reaffirms the positive message that CSR disclosure sends to the company's stakeholders. Furthermore, the findings suggest that two CSR disclosure categories, including environmental and social, have a negative impact on firm risk. These findings support the view that CSR activities (especially on environmental and social dimensions) are prominent in companies operating in high-risk sectors (e.g., controversial industry sectors such as alcohol, tobacco, gambling, mining, etc.). After controlling for affecting elements such as firm characteristics, business fields, utilizing the alternative measure of dependence variable, and dividing the sample into sub samples, the research results assure stability. In general, the research findings support the Stakeholder Theory rather than the Resource Theory in Vietnam, where CSR disclosure has a negative influence on the firm risk $[3,24,29,37,38,44]$.

The followings are some of the study's shortcomings. The study uses a sample of nonfinancial listed firms from a developing market. Due to changes in the institutional context, the results may not be generalizable to other nations in the area. Future studies might be conducted in the context of other developing nations, including comparisons of the findings. Second, mediating and moderating variables can alter the influence of corporate social responsibility disclosure on firm risk. However, this has not been addressed in the study, and this can serve as venue for future studies.

\subsection{Implications}

Based on the findings, this study suggests that publicly traded firms, particularly those in high-risk industries, should engage in CSR disclosure to mitigate firm risk to be able to lower the cost of capital. A lower cost of capital might be the result of reduced firm risk that follows CSR disclosure $[13,16,57,69,70]$. This is considered as a helpful signal of firm commitment to resolve the interests of stakeholders when firms provide the disclosure of CSR activities. This signal will be received by investors, who will either hold or purchase the stocks. As a result, the information asymmetry between investors and shareholders decreases.

The importance of CSR disclosure has been confirmed in this study, and it is now required to establish rules and standards for publishing CSR. The regulator should continue to develop legislative frameworks that instruct firms on how to handle and report material information. Investors, capital markets, and the regulators will all benefit from this. Disclosure items should be detailed and appropriate for each type of business, be transparent, distinguish between CSR implementation and information production and presentation, and the extent to which satisfaction of information disclosure requirements for with related parties.

Author Contributions: Conceptualization, C.T.M.T., N.V.K. and N.T.L.; Formal analysis, C.T.M.T., N.V.K. and N.T.L.; Investigation, C.T.M.T., N.T.L.; Methodology, C.T.M.T., N.V.K. and N.T.L.; Writingoriginal draft, C.T.M.T., N.V.K. and N.T.L.; Writing-review \& editing, C.T.M.T., N.V.K. and N.T.L. All of the authors contributed to the conceptualization, formal analysis, investigation, methodology, and writing and editing of the original draft. All authors have read and agreed to the published version of the manuscript. 
Funding: This research is funded by the University of Economics and Law, Vietnam National University Ho Chi Minh City, Vietnam.

Institutional Review Board Statement: Not applicable.

Informed Consent Statement: Informed consent was obtained from secondary data via Eikon Refinitive.

Data Availability Statement: The data will be made available on request.

Conflicts of Interest: The authors declare no conflict of interest.

\section{Appendix A}

According to the content analysis methodology based on the Global Reporting Initiative (GRI) 2016 criteria, the authors create a set of CSR disclosure scales. The information was gathered from the Annual Report and the Sustainability Report. The following is the content analysis approach used to determine the amount of CSR disclosure of listed firms in the sample. If each criteria in the GRI, Parts GRI 200, GRI 300, and GRI 400, has a qualitative and/or quantitative occurrence, that criterion obtains the value 1, otherwise the value 0 . The following is the method for determining the CSR score for each economic, environmental, and social dimensions, as well as the overall CSR score:

$$
\begin{aligned}
& \text { CSR_ECO } i=\frac{\sum X_{i}}{n_{i}} \\
& \text { CSR_ENV }_{i}=\frac{\sum X_{i}}{n_{i}} \\
& \text { CSR_SOC } i=\frac{\sum X_{i}}{n_{i}} \\
& \text { CSR_ALL } i=\frac{\sum X_{i}}{n_{i}}
\end{aligned}
$$

In which:

$\mathrm{CSR}_{\mathrm{ECO}} \mathrm{i}$ is the economic CSR score of the firm $\mathrm{i}, 0 \leq \mathrm{CSR} \mathrm{ECO} \leq 1$;

$\mathrm{CSR}_{\mathrm{ENV}} \mathrm{i}$ is the environmental CSR score of the firm $\mathrm{i}, 0 \leq \mathrm{CSR} E \mathrm{ENV} \leq 1$;

CSR_SOC $_{i}$ is the social CSR score of the firm $i, 0 \leq$ CSR_SOC $\leq 1$;

CSR_ALL $i$ is the overall CSR score of the firm $i, 0 \leq C S R \_A L L \leq 1$;

$X_{i}$ takes the value 1 if the firm meets criteria $i$; otherwise equal to 0 ;

$n_{i}$ is the expected number of criteria for the firm $i$, with a value from 1 to 6 with an economic dimension (GRI 200), a value from 1 to 8 with an environmental dimension (GRI 300), with value from 1 to 19 with social dimension (GRI 400).

\section{References}

1. Ali, I.; Rehman, K.U.; Ali, S.I.; Yousaf, J.; Zia, M. Corporate social responsibility influences, employee commitment and organizational performance. Afr. J. Bus. Manag. 2010, 4, 2796-2801.

2. Riahi-Belkaoui, A. Intellectual capital and firm performance of US multinational firms: A study of the resource-based and stake-holder views. J. Intellect. Cap. 2003, 4, 215-226. [CrossRef]

3. Minor, D.; Morgan, J. CSR as Reputation Insurance: Primum Non Nocere. Calif. Manag. Rev. 2011, 53, 40-59. [CrossRef]

4. Munodawafa, R.T.; Johl, S.K. A Systematic Review of Eco-Innovation and Performance from the Resource-Based and Stakeholder Perspectives. Sustainability 2019, 11, 6067. [CrossRef]

5. Burlea-Schiopoiu, A.; Mihai, L.S. An Integrated Framework on the Sustainability of SMEs. Sustainability 2019, 11, 6026. [CrossRef]

6. McWilliams, A. Corporate Social Responsibility; Wiley Encyclopedia of Management: Hoboken, NJ, USA, 2015 ; pp. 1-4.

7. McGuire, J.B.; Sundgren, A.; Schneeweis, T. Corporate social responsibility and firm financial performance. Acad. Manag. J. 1988, 31, 854-872.

8. RED and Pro NGO! e.V. Win-Win for Vietnam. 2021. Available online: http://www.visible-impact.eu/?p=1838 (accessed on 14 November 2021). 
9. SSC and IFC, Hướng Dẫn Lập Báo Cáo Phát Triển Bền Vững. 2013. Available online: http://www.ssc.gov.vn/ubck/ contentattachfile $/$ idcplg?dID=78866\&dDocName=APPSSCGOVVN162078672\&Rendition=SSC $\% 20 I F C \% 20 H u o n g \% 20 \mathrm{dan} \% 20$ lap $\% 20$ Bao $\% 20$ cao $\% 20$ Phat $\% 20$ trien $\% 20$ ben $\% 20$ vung.pdf\&filename=SSC $\% 20 \mathrm{IFC} \% 20 \mathrm{Huong} \% 20 \mathrm{dan} \% 201 \mathrm{ap} \% 20 \mathrm{Bao} \% 20 \mathrm{cao} \%$ 20Phat\%20trien\%20ben\%20vung.pdf (accessed on 14 November 2021).

10. VNM. Sustainable Development Report. 2012. Available online: https://vinamilk.com.vn/static/uploads/article/1410163343 -b69818be4182ad8a8559b56ed41f4ea9133297ecfeb78f7c0db3ce4c2475da88..pdf (accessed on 14 November 2021).

11. DHG. Sustainable Development Reports. 2015. Available online: https://www.dhgpharma.com.vn/images/B.Codong.2016/201 60606_BaoCaoPhatTrienBenVung2015DHGPharma.pdf (accessed on 14 November 2021).

12. VCS. Sustainable Development Reports. 2014. Available online: https://vicostone.com/en/annual-reports/2014/vicostonecong-bo-bao-cao-phat-trien-ben-vung-nam-2014 (accessed on 14 November 2021).

13. Reverte, C. The Impact of Better Corporate Social Responsibility Disclosure on the Cost of Equity Capital. Corp. Soc. Responsib. Environ. Manag. 2011, 19, 253-272. [CrossRef]

14. Jo, H.; Na, H. Does CSR Reduce Firm Risk? Evidence from Controversial Industry Sectors. J. Bus. Ethics 2012, 110, 441-456. [CrossRef]

15. Benlemlih, M.; Shaukat, A.; Qiu, Y.; Trojanowski, G. Environmental and Social Disclosures and Firm Risk. J. Bus. Ethics 2016, 152, 613-626. [CrossRef]

16. Goss, A.; Roberts, G.S. The impact of corporate social responsibility on the cost of bank loans. J. Bank. Financ. 2011, 35, 1794-1810. [CrossRef]

17. Gunawan, L. Pengaruh Family Control, Firm Risk, Size, dan Age Terhadap Profitabilitas dan Nilai Perusahaan Pada Sektor Perdagangan, Jasa, dan Investasi. Bus. Account. Rev. 2014, 2, 41-50.

18. Liu, M.; Lu, W. Corporate social responsibility, firm performance, and firm risk: The role of firm reputation. Asia-Pac. J. Account. Econ. 2021, 28, 525-545. [CrossRef]

19. Nguyen, P.; Nguyen, A. The effect of corporate social responsibility on firm risk. Soc. Responsib. J. 2015, 11, 324-339. [CrossRef]

20. Rehman, Z.; Khan, A.; Rahman, A. Corporate social responsibility's influence on firm risk and firm performance: The mediating role of firm reputation. Corp. Soc. Responsib. Environ. Manag. 2020, 27, 2991-3005. [CrossRef]

21. Thanaya, S.A.; Widanaputra, A. The Effect of CSR Disclosure on Firm Risk in Mining Companies Listed on IDX. E-Jurnal Akunt. 2019, 29, 577. [CrossRef]

22. Branco, M.C.; Rodrigues, L. Corporate Social Responsibility and Resource-Based Perspectives. J. Bus. Ethic 2006, 69, 111-132. [CrossRef]

23. Chiu, T.-K.; Wang, Y.-H. Determinants of Social Disclosure Quality in Taiwan: An Application of Stakeholder Theory. J. Bus. Ethic. 2015, 129, 379-398. [CrossRef]

24. Aribi, Z.A.; Alqatamin, R.M.; Arun, T. Gender diversity on boards and forward-looking information disclosure: Evidence from Jordan. J. Account. Emerg. Econ. 2018, 8, 205-222. [CrossRef]

25. Matuszak, Ł.; Różańska, E. Online corporate social responsibility (CSR) disclosure in the banking industry: Evidence from Poland. Soc. Responsib. J. 2019, 16, 1191-1214. [CrossRef]

26. Vitolla, F.; Raimo, N.; Rubino, M.; Garzoni, A. How pressure from stakeholders affects integrated reporting quality. Corp. Soc. Responsib. Environ. Manag. 2019, 26, 1591-1606. [CrossRef]

27. Luo, X.; Bhattacharya, C.B. Corporate social responsibility, customer satisfaction, and market value. J. Mark. 2006, 70, 1-18. [CrossRef]

28. Klein, J.; Dawar, N. Corporate social responsibility and consumers' attributions and brand evaluations in a product-harm crisis. Int. J. Res. Mark. 2004, 21, 203-217. [CrossRef]

29. Boesso, G.; Kumar, K. Drivers of corporate voluntary disclosure: A framework and empirical evidence from Italy and the United States. Account. Audit. Account. J. 2007, 20, 269-296. [CrossRef]

30. Porter, M.E.; Kramer, M.R. Strategy and society: The link between corporate social responsibility and competitive advantage. Harv. Bus. Rev. 2006, 84, 78-92. [PubMed]

31. Hardjono, T.; de Klein, P. Introduction on the European corporate sustainability framework (ECSF). J. Bus. Ethics 2004, 55, 99-113. [CrossRef]

32. Buchholz, R.A.; Rosenthal, S.B. Toward a Contemporary Conceptual Framework for Stakeholder Theory. J. Bus. Ethics 2005, 58, 137-148. [CrossRef]

33. Patten, D.M. Intra-industry environmental disclosures in response to the Alaskan oil spill: A note on legitimacy theory. Account. Organ. Soc. 1992, 17, 471-475. [CrossRef]

34. Post, J.; Preston, L.E. Private Management and Public Policy: The Principle of Public Responsibility; Stanford University Press: Redwood City, CA, USA, 2012.

35. Forte, W.; Matonti, G.; Nicolo, G.; Tucker, J. MtB versus VAIC in measuring intellectual capital: Empirical evidence from Italian listed companies. Afr. J. Bus. Manag. 2019, 13, 588-601.

36. Nicolò, G.; Aversano, N.; Sannino, G.; Polcini, P.T. ICD corporate communication and its determinants: Evidence from Italian listed companies' websites. Meditari Account. Res. 2020, 29, 1209-1232. [CrossRef]

37. Nicolò, G.; Ricciardelli, A.; Raimo, N.; Vitolla, F. Visual disclosure through integrated reporting. Manag. Decis. 2021. ahead-ofprint. [CrossRef] 
38. Wang, J.; Li, J.; Zhang, Q. Does carbon efficiency improve financial performance? Evidence from Chinese firms. Energy Econ. 2021, 104, 105658. [CrossRef]

39. Kytle, B.; Ruggie, J.G. Corporate Social Responsibility as Risk Management: A Model for Multinationals; Corporate Social Responsibility Initiative Working Paper No. 10; John F. Kennedy School of Government, Harvard University: Cambridge, MA, USA, 2005.

40. Husted, B.W. Risk management, real options, corporate social responsibility. J. Bus. Ethics 2005, 60, 175-183. [CrossRef]

41. Spicer, B.H. Investors, corporate social performance and information disclosure: An empirical study. Account. Rev. 1978, 53, 94-111.

42. Aupperle, K.E.; Carroll, A.B.; Hatfield, J.D. An empirical examination of the relationship between corporate social responsi-bility and profitability. Acad. Manag. J. 1985, 28, 446-463.

43. Alexander, G.J.; Buchholz, R.A. Corporate social responsibility and stock market performance. Acad. Manag. J. 1978, 21, 479-486. [CrossRef]

44. Abhayawansa, S.; Abeysekera, I. An explanation of human capital disclosure from the resource-based perspective. J. Hum. Resour. Costing Account. 2008, 12, 51-64. [CrossRef]

45. Vitolla, F.; Raimo, N.; Rubino, M.; Garzoni, A. The impact of national culture on integrated reporting quality. A stakeholder theory approach. Bus. Strat. Environ. 2019, 28, 1558-1571. [CrossRef]

46. Becchetti, L.; Palestini, A.; Solferino, N.; Tessitore, M.E. The socially responsible choice in a duopolistic market: A dynamic model of "ethical product" differentiation. Econ. Model. 2014, 43, 114-123. [CrossRef]

47. Barnea, A.; Rubin, A. Corporate Social Responsibility as a Conflict between Shareholders. J. Bus. Ethics 2010, 97, 71-86. [CrossRef]

48. Boutin-Dufresne, F.; Savaria, P. Corporate Social Responsibility and Financial Risk. J. Inv. 2004, 13, 57-66. [CrossRef]

49. Lee, D.D.; Faff, R.W. Corporate Sustainability Performance and Idiosyncratic Risk: A Global Perspective. Financ. Rev. 2009, 44, 213-237. [CrossRef]

50. Oikonomou, I.; Brooks, C.; Pavelin, S. The Impact of Corporate Social Performance on Financial Risk and Utility: A Longitudinal Analysis. Financ. Manag. 2012, 41, 483-515. [CrossRef]

51. Bhattacharya, C.B.; Korschun, D.; Sen, S. Strengthening Stakeholder-Company Relationships Through Mutually Beneficial Corporate Social Responsibility Initiatives. J. Bus. Ethics 2008, 85, 257-272. [CrossRef]

52. McAlister, L.; Srinivasan, R.; Kim, M. Advertising, research and development, and systematic risk of the firm. J. Mark. 2007, 71, 35-48. [CrossRef]

53. Albuquerque, R.; Durnev, A.; Koskinen, Y. Corporate Social Responsibility and Asset Pricing in Industry Equilibrium. 2012. Available online: https:/ / ssrn.com/abstract=1961971 (accessed on 14 November 2021).

54. Albuquerque, R.; Koskinen, Y.; Zhang, C. Corporate Social Responsibility and Firm Risk: Theory and Empirical Evidence. Manag. Sci. 2019, 65, 4451-4469. [CrossRef]

55. Barney, J.B. The Resource-Based Theory of the Firm. Organ. Sci. 1996, 7, 469. [CrossRef]

56. Freeman, R.B.; Medoff, J.L. What do unions do. Indus. Lab. Rel. Rev. 1984, 38, 244.

57. Dhaliwal, D.S.; Li, O.Z.; Tsang, A.; Yang, Y.G. Voluntary Nonfinancial Disclosure and the Cost of Equity Capital: The Initiation of Corporate Social Responsibility Reporting. Account. Rev. 2011, 86, 59-100. [CrossRef]

58. Cai, Y.; Jo, H.; Pan, C. Doing Well While Doing Bad? CSR in Controversial Industry Sectors. J. Bus. Ethics 2011, 108, 467-480. [CrossRef]

59. Godfrey, P.C.; Merrill, C.B.; Hansen, J.M. The relationship between corporate social responsibility and shareholder value: An empirical test of the risk management hypothesis. Strat. Manag. J. 2008, 30, 425-445. [CrossRef]

60. Kramer. Strategy and society: The link between competitive advantage and corporate social responsibility-response. Harv. Bus. Rev. 2007, 85, 139 .

61. Jizi, M.; Nehme, R.; Salama, A. Do social responsibility disclosures show improvements on stock price? J. Dev. Areas 2016, 50, 77-95. [CrossRef]

62. Jizi, M.I.; Salama, A.; Dixon, R.; Stratling, R. Corporate governance and corporate social responsibility disclosure: Evidence from the US banking sector. J. Bus. Ethics 2014, 125, 601-615. [CrossRef]

63. Tasnia, M.; AlHabshi, S.M.S.J.; Rosman, R. The impact of corporate social responsibility on stock price volatility of the US banks: A moderating role of tax. J. Financ. Rep. Account. 2020, 19, 77-91. [CrossRef]

64. Boubaker, S.; Cellier, A.; Manita, R.; Saeed, A. Does corporate social responsibility reduce financial distress risk? Econ. Model. 2020, 91, 835-851. [CrossRef]

65. Sun, W.; Cui, K. Linking corporate social responsibility to firm default risk. Eur. Manag. J. 2014, 32, 275-287. [CrossRef]

66. Tabachnick, B.G.; Fidell, L.S.; Ullman, J.B. Using Multivariate Statistics; Pearson: Boston, MA, USA, 2007 ; Volume 5.

67. Sassen, R.; Hinze, A.-K.; Hardeck, I. Impact of ESG factors on firm risk in Europe. J. Bus. Econ. 2016, 86, 867-904. [CrossRef]

68. Shakil, M.H. Environmental, social and governance performance and stock price volatility: A moderating role of firm size. J. Public Aff. 2020, e2574. [CrossRef]

69. Chava, S. Environmental Externalities and Cost of Capital. Manag. Sci. 2014, 60, 2223-2247. [CrossRef]

70. El Ghoul, S.; Guedhami, O.; Kwok, C.C.; Mishra, D.R. Does corporate social responsibility affect the cost of capital? J. Bank. Financ. 2011, 35, 2388-2406. [CrossRef] 